\section{Penentuan Kapabilitas Transfer Daya Listrik dengan Mempertimbangkan Stabilitas Tegangan Statis Menggunakan L Index}

\author{
Al Imran \\ Universitas Negeri Makassar \\ Email:al.imran@unm.ac.id
}

Abstrak. Metode penentuan ATC pada penelitian ini menggunakan batasan termal saluran dengan memperhitungkan aliran daya reaktif, dan menggunakan Linear Power Transfer Distribution Factor. Penentuan ATC mempertimbangkan besar magnitude tegangan dan kestabilan tegangan statis tiap bus setelah simulasi transfer daya dilakukan. Kestabilan tegangan statis dihitung dengan menggunakan $L$ Index. Hasil penelitian menunjukkan bahwa transfer daya sebesar nilai ATC pada suatu sistem tenaga listrik menyebabkan penurunan kestabilan tegangan atau peningkatan nilai $L$ index pada bus penerima rata-rata 19 kali lipat dari kondisi pembebanan awal, meskipun masih berada pada level stabil. Sedangkan magnitude tegangan bus penerima mengalami penurunan rata-rata $12 \%$ dari kondisi pembebanan awal.

Kata Kunci: Kapabilitas transfer, Available Transfer Capability (ATC), LPTDF, kestabiltas tegangan statis, dan $L$ index.

\section{INDONESIAN JOURNAL OF FUNDAMENTAL SCIENCES (IJFS)}

\section{E-ISSN: 2621-6728 \\ P-ISSN: 2621-671X}

Submitted: June, $22^{\text {th }} 2019$

Accepted : August, $13^{\text {th }} 2019$

Abstract. The ATC determination method in this study uses line thermal constraints by calculating reactive power flow, and using Linear Power Transfer Distribution Factor. The ATC determination considers the magnitude of the voltage magnitude and the static voltage stability of each bus after the power transfer simulation is performed. Static voltage stability is calculated using the $L$ Index. The results showed that the transfer of power equal to the ATC value in an electric power system caused a decrease in voltage stability or an increase in the $L$ index value on the receiving bus on average 19 times the initial loading condition, even though it was still at a stable level. While the receiver bus voltage magnitude has decreased 


\section{PENDAHULUAN}

Suatu sistem tenaga yang terinterkoneksi dengan beberapa sistem tenaga lainnya dapat membentuk suatu jaringan kerja sama operasi dan memungkinkan terjadinya pertukaran energi listrik antar sistem. Hal ini akan menyebabkan lalu lintas energi dalam jaringan transmisi menjadi kompleks, akibat energi yang dipertukarkan tadi akan melewati setiap jaringan dengan mengikuti hukum Kirchhoff. Setiap injeksi daya pada sisi pembangkitan akan menaikkan daya yang mengalir pada jaringan transmisi. Karena itu, perlu didefinisikan secara kuantitas daya maksimum yang dapat di injeksikan pada sisi pembangkitan atau yang dapat ditransfer sehingga aliran daya yang melewati jaringan tidak melanggar kriteria kehandalan dan keamanan sistem tenaga. Untuk keperluan ini, North American Electric Realibility Council (NERC) telah mendefinisikan secara kuantitas daya maksimum tersebut yang disebut dengan kapabilitas transfer (transfer capability) (NERC, 1995).

Setahun kemudian NERC kembali menerbitkan sebuah dokumen yang melahirkan istilah Available Transfer Capability (ATC), yang merupakan kuantitas daya tambahan maksimum yang dapat ditransfer dengan aman pada jaringan tanpa melanggar kriteria kehandalan dan keamanan sistem tenaga (NERC, 1996). Kuantitas ini perlu diketahui oleh setiap pengguna jaringan untuk kemudian diperlukan kesepakatan untuk tetap beroperasi sesuai kriteria tersebut. Pada perencanaan dan pelaksanaan transfer atau transaksi daya yang besar, penentuan ATC secara akurat merupakan hal yang sangat vital. Ini penting bagi perencana untuk mengetahui tingkat kesesakan sistem tenaga dan bagi operator juga penting untuk tidak melakukan transfer daya melampaui nilai ATC dari hasil perhitungan. Perkiraan nilai ATC harus diperbaharui secara teratur atau setiap setelah terjadi perubahan beban atau perubahan konfigurasi jaringan untuk menghindari efek dari transfer daya yang dapat menyebabkan resiko yang tidak semestinya terjadi, seperti saluran yang mengalami pembebanan lebih (overload), kerusakan peralatan, atau pemadaman total (blackout).

Pada suatu sistem tanaga yang besar yang saling terinterkoneksi yang di dalamnya sudah diterapkan pasar tenaga listrik, dimana dimungkinkan jual beli daya listrik antara satu area dengan area lainnya, peningkatan kapabilitas transfer dari segi jumlah dan variasi arah transfernya sangat diperlukan agar menjadi lebih kompetitif. Karena itu peningkatan tingkat ketelitian dan efektivitas dalam perhitungan ATC menjadi sangat penting.

Pada suatu sistem tenaga listrik, yang telah menerapkan pasar bebas listrik, sangat memungkinkan dilakukan jual beli daya listrik antar bus atau antar area. Nilai ATC sangat diperlukan oleh operator sebagai acuan agar dalam melakukan transfer daya listrik dari bus pembangkit ke bus beban atau dari bus yang satu ke bus lainnya tidak melebihi nilai ATC-nya, meskipun kapasitas daya pada bus pembangkit (spinning reserve) masih mencukupi. Dengan demikian sistem tenaga listrik dapat terhindar dari gangguan-gangguan seperti yang telah disebutkan di atas, yaitu saluran trasnmisi yang kelebihan beban, kerusakan peralatan, atau pemadaman total sehingga kontinuitas penyaluran daya listrik tetap terjaga. 
Metode perhitungan ATC dikembangkan dari penggunaan metode linear untuk menghitung perubahan aliran daya pada saluran sebagai respons atas injeksi daya pada bus, seperti yang dilakukan oleh Wood-Wollenberg (1996) dan B. Stott and J.L. Marinho (1979). Kemudian NERC memperkenalkan metode perhitungan ATC secara linear dengan mempergunakan Power Transfer Distribution Factor (PTDF) linear atau Faktor Distribusi Perpindahan Daya linear pada tahun 1995, yang waktu itu diistilahkan dengan nama FCITC (First Contingency Incremental Transfer Capability), dan tahun 1996 dengan istilah ATC. Kemudian pada tahun 1997, P.W. Sauer memperkenalkan beberapa issu-issu penting yang berkaitan dengan perhitungan ATC, seperti ketidakpastian kondisi sistem (uncertainty), yang kemudian melahirkan istilah Transmission Reliability Margin (TRM). Ini kemudian diperhatikan dalam perhitungan-perhitungan ATC selanjutnya. G.C. Ejebe, et all. (1998) memperkenalkan metode perhitungan ATC menggunakan Continuation Power Flow (CPF), mempertimbangkan batasan tegangan, dan Voltage Collapse, tetapi membutuhkan beban komputasi yang berat.

Perbaikan perhitungan ATC telah dilakukan oleh Santiago Grijalva (2003) dengan memperhitungkan aliran daya reaktif saluran. Al Imran (2006) melakukan perbaikan perhitungan ATC dengan menggunakan Nonlinear Power Transfer Distribiution Factor (NLPTDF). Peningkatan nilai ATC sekarang ini banyak dilakukan tanpa mengubah kapasitas saluran dan struktur jaringan transmisi, tapi dengan penambahan piranti FACTS (Flexible AC Transmission System) pada sistem tenaga, seperti yang dilakukan oleh Y. R. H. Esmaili, A. M. A. Hemmatyar (2012), T. Nireekshana, G. K. Rao, and S. S. Raju (2016), K. Bavithra, S. C. Raja, and P. Venkates (2016), dan lain-lain. Optimasi lokasi penempatan dan ukuran FACTS banyak dilakukan dengan metode-metode optimisasi metaheuristik dan teknik kecerdasan buatan.

Penentuan besar dan peningkatan nilai kapabilitas transfer daya listrik yang banyak disebutkan di atas dihitung berdasarkan batasan termal saluran, belum mempertimbangkan kestabilan tegangan sistem tenaga, khususnya pada bus-bus tujuan transfer atau bus penerima. Artkel ini memperkenalkan metode penentuan ATC dengan mempertimbangkan stabiltas tegangan statis bus yang dihitung dengan menggunakan $L$ Index. Kestabilan tegangan statis sistem tenaga menggunakan $L$ Index diperkenalkan oleh pertama kali oleh Huang, Garng M., and Ali Abur. (2002).

\section{METODE PENELITIAN}

Penentuan kapabilitas transfer daya listrik, dalam hal ini ATC pada penelitian ini dihitung berdasarkan batasan termal saluran dengan mempertimbangkan kestabilan tegangan statis sistem tenaga menggunakan $L$ Index., yang dihitung dengan langkah-langkah sebagai berikut:

1. Hitung analisis aliran daya menggunakan metode Newton-Raphson untuk menentukan kondisi pembebanan awal.

2. Hitung $L$ Index sistem tenaga pada kondisi pembebanan awal

3. Hitung Matriks Impedansi Bus ( $Z_{\text {bus }}$ )

4. Hitung Linear Power Transfer Distribution Factor (LPTDF) dari Matriks $Z_{\text {bus. }}$ 
5. Hitung $P_{j k}^{\max }$ yaitu batasan aliran daya aktif maksimum yang mengalir pada saluran $j-k$, yang diturungkan dari kemampuan daya semu maksimum saluran, $S_{j k}^{\max }$ (MVA). (Santiago Grijalva, 2003)

6. Tentukan arah transfer, misalkan dari bus $\mathrm{p}$ ke bus $\mathrm{q}(\mathrm{p} \rightarrow \mathrm{q})$

7. Hitung nilai margin transfer, $\Delta P_{p}^{j k}$ yang boleh dibangkitkan pada bus pembangkitan $p$ (source bus) dengan batasan setiap saluran $j-k$, jika terjadi transfer daya dari bus $p$ ke bus $q$ dengan menggunakan persamaan (1).

8. Hitung besar nilai ATC dengan menggunakan persamaan (2).

9. Simulasikan transfer daya sebesar nilai ATC dengan menghitung analisis aliran daya, untuk melihat tegangan bus penerima, rugi-rugi total (total loss), dan tegangan minimum dan maksimum bus.

10. Verifikasi apakah ada bus-bus yang perubahan magnitude tegangannya setelah transfer daya dilakukan melampaui batas-batas yang diizinkan $\left(0,90 \mathrm{pu} \leq \mathrm{V}_{\text {Bus }} \leq 1,05 \mathrm{pu}\right)$.

11. Hitung $L$ Index sistem tenaga setelah transfer daya dilakukan

12. Verifikasi nilai $L$ Index pada setiap bus, khususnya pada bus penerima apakah ada yang melampaui batas-batas stabilitasnya ( $\leq L$ Index $\leq 1,0)$.

Secara matematis, nilai margin transfer $\Delta P_{p}^{j k}$ yang boleh dibangkitkan pada bus pembangkitan $p$ (source bus) dengan batasan setiap saluran $j-k$, jika terjadi transfer daya dari bus $p$ ke bus $q$ adalah sebagai berikut : (Santiago Grijalva, 2003; PowerWorld Corp., 2004):

$$
\begin{aligned}
\Delta P_{p}^{j k} & =\frac{P_{j k}^{\max }-P_{j k}^{o}}{P T D F_{j k, p q}} \text { untuk } P T D F_{j k, p q}>0, \text { atau } \\
\Delta P_{p}^{j k} & =\frac{-P_{j k}^{\max }-P_{j k}^{o}}{P T D F_{j k, p q}} \quad \text { untuk } P T D F_{j k, p q}<0
\end{aligned}
$$

$P_{j k}^{\max }$ adalah batasan aliran daya aktif maksimum yang mengalir pada saluran $j-k$, yang diturungkan dari kemampuan daya semu maksimum saluran, $S_{j k}^{\max }$ (MVA). Metode penentuan $P_{j k}^{\max }$ telah dilakukan oleh Santiago Grijalva (2003). $P_{j k}^{o}$ adalah pembebanan saluran $j-k$, atau daya yang mengalir pada saluran $j-k$ pada keadaan awal, yang pada penelitian ini diperoleh dari analisis aliran daya AC metode Newton Raphson. PTDF $j k, p q$ adalah Faktor Distribusi Perpindahan Daya atau Power Transfer Distribution Factor (PTDF) untuk setiap saluran j-k jika terjadi transfer daya dari bus $p$ ke bus $q$. Dan nilai ATC sistem adalah nilai minimum dari $\Delta P_{p}^{j k}$ dari semua saluran $j$-k pada sistem, yaitu

$$
A T C_{p \rightarrow q}=\min \left\{\Delta P_{p}^{j k}\right\} \quad \text { : dari semua saluran } j-k \text {. }
$$

Perhitungan ATC ini dengan menganggap bahwa daya transfer yang terjadwal tetap (base scheduled transfers) tidak ada, dan Transmission Reliability Margin (TRM) diperhitungkan di akhir perhitungan sebesar 8 \% (Grijalva, S. and Peter W. Sauer, 1999). TRM didefinisikan sebagai sejumlah transfer capability yang diperlukan untuk menjamin bahwa jaringan transmisi beroperasi dalam batasbatas yang aman karena pengaruh ketidakpastian (uncertainty) kondisi sistem. 
Metode perhitungan ATC dengan mempertimbangkan kestabilan tegangan pada penelitian ini diujicoba pada IEEE 30 bus test system terdiri dari 30 bus dan 41 saluran (Gambar 1). Data-data bus, pembangkitan, beban dan kapasitas saluran diambil dari M.A. Pai (1984). Semua perhitungan matematis dihitung menggunakan program komputer bahasa pemrograman MATLAB.

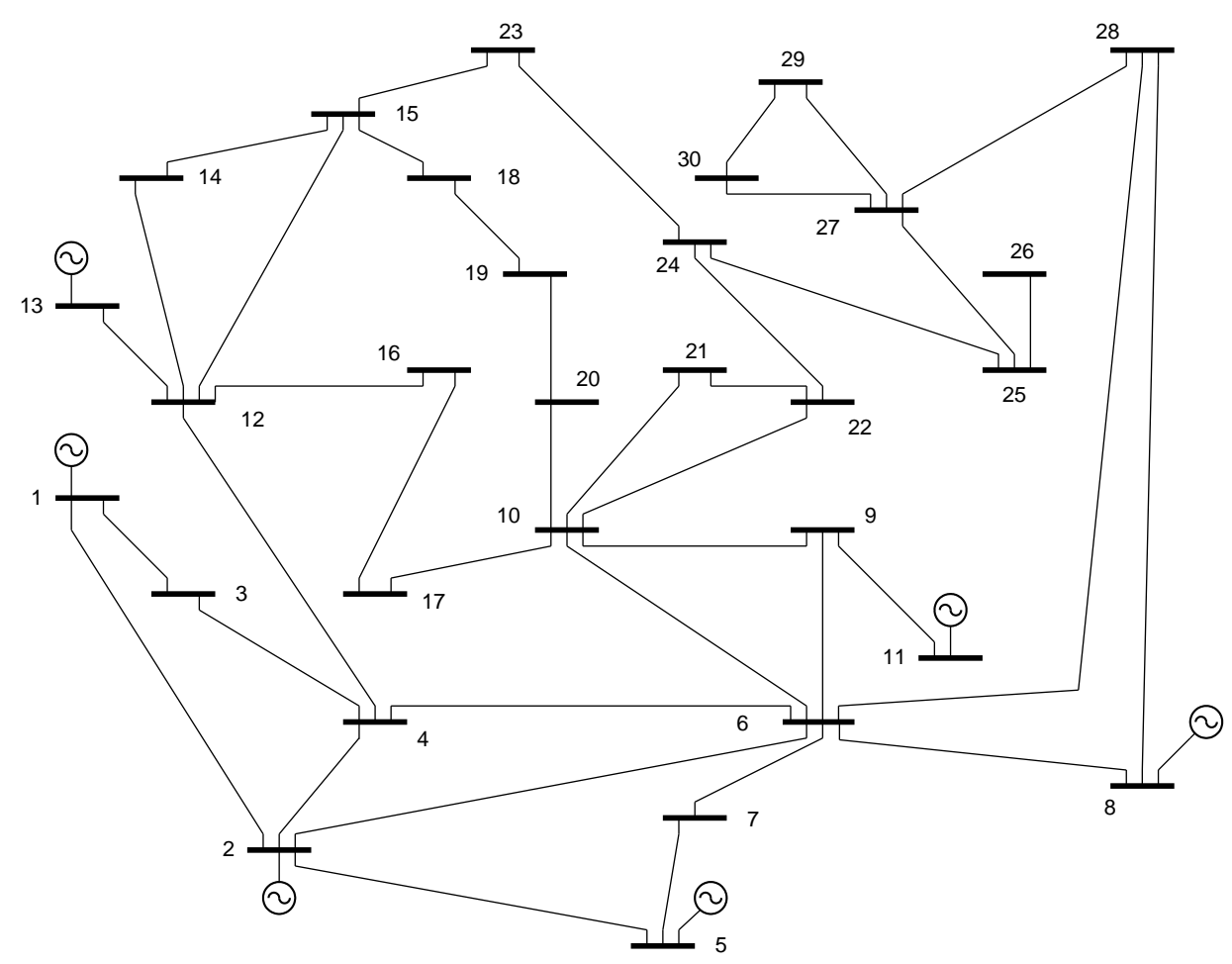

Gambar 1.

Single Line Diagram IEEE 30 bus test system

(Sumber: M.A. Pai, 1984)

\section{HASIL DAN PEMBAHASAN}

Kapasitas transfer daya listrik dalam hal ini adalah Available Transfer Capacity (ATC) adalah besarnya daya listrik tambahan dari kondisi pembebanan awal yang dapat di transfer dari suatu bus pembangkit ke suatu bus beban atau bus pembangkit lainnya yang mempunyai beban dengan aman, dimana kondisi sistem tenaga tetap stabil dan normal. Nilai ATC ini dihitung dengan menggunakan persamaan (2) untuk berbagai arah transfer.

Transfer daya dilakukan pada 15 arah transfer yang berbeda, yaitu transfer daya dari bus 1 ke bus $14(1 \rightarrow 14), 1 \rightarrow 16,1 \rightarrow 20,2 \rightarrow 7,2 \rightarrow 12,2 \rightarrow 21,8 \rightarrow 3$, 8 $\rightarrow 15,8 \rightarrow 30,11 \rightarrow 3,11 \rightarrow 14,11 \rightarrow 23,13 \rightarrow 10,13 \rightarrow 19$, dan $13 \rightarrow 23$. Setelah nilai ATC diperoleh pada setiap arah transfer, dihitunglah kembali indeks kestabilan tegangan, yaitu indeks $L$ untuk setiap arah transfer, dan hasilnya dapat dilihat pada Tabel 1, Tabel 2 dan Tabel 3. Pada penelitian ini juga dihitung tegangan minimum (Vmin, pu), tegangan pada bus penerima (Vbus-q, pu), dan persentase besar perbedaan indeks $L$ pada kondisi pembebanan awal dengan kondisi setelah 
transfer di bus tujuan transfer (bus q), seperti yang ditunjukkan pada tabel 1, tabel 2 dan tabel 3.

Tabel 1. Nilai ATC, dan Indeks L pada bus penerima (q) sebelum dan setelah transfer daya dengan bus 1 dan bus 2 sebagai bus pengirim (bus $p$ )

\begin{tabular}{|c|c|c|c|c|c|c|}
\hline & & & Transfe & $(p \rightarrow q)$ & & \\
\hline & $1 \rightarrow 14$ & $1 \rightarrow 16$ & $1 \rightarrow 20$ & $2 \rightarrow 7$ & $2 \rightarrow 12$ & $2 \rightarrow 21$ \\
\hline $\operatorname{ATC}(\mathrm{pu})$ & 0,4598 & 0,5470 & 0,7114 & 1,0760 & 0,4278 & 0,9114 \\
\hline Indeks $L_{o}$ Bus q & 0,0089 & 0,0039 & 0,0013 & 0,0127 & 0,0049 & 0,0039 \\
\hline Indeks $L_{1}$ Bus q & 0,0885 & 0,0787 & 0,0566 & 0,0812 & 0,0248 & 0,0337 \\
\hline Vbus $_{0}-q(p u)$ & 1,033 & 1,038 & 1,025 & 1,008 & 1,047 & 1,030 \\
\hline Vbus $_{1}-q(p u)$ & 0,950 & 0,945 & 0,881 & 0,953 & 1,018 & 0,873 \\
\hline $\operatorname{Vmin}_{0}(\mathrm{pu})$ & $\begin{array}{c}1,005 \\
\text { (bus 30) }\end{array}$ & $\begin{array}{c}1,005 \\
\text { (bus 30) }\end{array}$ & $\begin{array}{c}1,005 \\
\text { (bus 30) }\end{array}$ & $\begin{array}{c}1,005 \\
\text { (bus 30) }\end{array}$ & $\begin{array}{c}1,005 \\
\text { (bus 30) }\end{array}$ & $\begin{array}{c}1,005 \\
\text { (bus 30) }\end{array}$ \\
\hline $\operatorname{Vmin}_{1}(p u)$ & $\begin{array}{c}0,950 \\
\text { (bus 14) }\end{array}$ & $\begin{array}{c}0,945 \\
\text { (bus 16) }\end{array}$ & $\begin{array}{c}0,881 \\
\text { (bus 20) }\end{array}$ & $\begin{array}{c}0,953 \\
\text { (bus 7) }\end{array}$ & $\begin{array}{c}0,999 \\
\text { (bus 26) }\end{array}$ & $\begin{array}{c}0,873 \\
\text { (bus 21) }\end{array}$ \\
\hline Vmax (pu) & $\begin{array}{c}1.091 \\
\text { (bus 11) }\end{array}$ & $\begin{array}{c}1,091 \\
\text { (bus 11) }\end{array}$ & $\begin{array}{c}1,091 \\
\text { (bus 11) }\end{array}$ & $\begin{array}{c}1,091 \\
\text { (bus 11) }\end{array}$ & $\begin{array}{c}1,091 \\
\text { (bus 11) }\end{array}$ & $\begin{array}{c}1,091 \\
\text { (bus 11) }\end{array}$ \\
\hline Total Loss。 & $\begin{array}{c}7,110 \mathrm{MW} \\
2,081 \\
\text { MVAR }\end{array}$ & $\begin{array}{c}7,110 \mathrm{MW} \\
2,081 \\
\text { MVAR }\end{array}$ & $\begin{array}{c}7,110 \mathrm{MW} \\
2,081 \\
\text { MVAR }\end{array}$ & $\begin{array}{c}7,110 \mathrm{MW} \\
2,081 \\
\text { MVAR }\end{array}$ & $\begin{array}{c}7,110 \mathrm{MW} \\
2,081 \\
\text { MVAR }\end{array}$ & $\begin{array}{c}7,110 \mathrm{MW} \\
2,081 \\
\text { MVAR }\end{array}$ \\
\hline Total Loss & $\begin{array}{c}14,181 \\
\text { MW } \\
26,977 \\
\text { MVAR }\end{array}$ & $\begin{array}{c}14,525 \\
\text { MW } \\
33,601 \\
\text { MVAR }\end{array}$ & $\begin{array}{c}21,758 \\
\text { MW } \\
58,279 \\
\text { MVAR }\end{array}$ & $\begin{array}{c}18,726 \\
\text { MW } \\
39,025 \\
\text { MVAR }\end{array}$ & $\begin{array}{c}8,974 \\
\text { MW } \\
14,552 \\
\text { MVAR }\end{array}$ & $\begin{array}{c}20,516 \\
\text { MW } \\
67,749 \\
\text { MVAR }\end{array}$ \\
\hline $\begin{array}{l}\text { Saluran } \\
\text { Pembatas }\end{array}$ & $12-4$ & $12-4$ & $12-4$ & $2-6$ & $12-4$ & $12-4$ \\
\hline
\end{tabular}


Tabel 2. Nilai ATC, dan Indeks L pada bus penerima (q) sebelum dan setelah transfer daya dengan bus 8 dan bus 11 sebagai bus pengirim (bus $p$ )

\begin{tabular}{|c|c|c|c|c|c|c|}
\hline & & & Transfe & $(p \rightarrow q)$ & & \\
\hline & $8 \rightarrow 3$ & $8 \rightarrow 15$ & $8 \rightarrow 30$ & $11 \rightarrow 3$ & $11 \rightarrow 14$ & $11 \rightarrow 23$ \\
\hline ATC (pu) & 0,5051 & 0,5168 & 0,3008 & 0,6130 & 0,5473 & 0,6130 \\
\hline Indeks $L_{0}$ Bus q & 0,0008 & 0,0044 & 0,0312 & 0,0008 & 0,0089 & 0,0044 \\
\hline Indeks $L_{1}$ Bus q & 0,0192 & 0,0354 & 0,1840 & 0,0233 & 0,1077 & 0,1266 \\
\hline 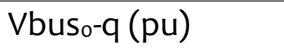 & 1,033 & 1,030 & 1,005 & 1,033 & 1,033 & 1,022 \\
\hline Vbus $_{1}-q(p u)$ & 1,011 & 0,976 & 0,811 & 1,008 & 0,930 & 0,857 \\
\hline$V_{\min }(\mathrm{pu})$ & $\begin{array}{c}1,005 \\
\text { (bus 30) }\end{array}$ & $\begin{array}{c}1,005 \\
\text { (bus 30) }\end{array}$ & $\begin{array}{l}1,005 \\
\text { (bus 30) }\end{array}$ & $\begin{array}{l}1,005 \\
\text { (bus 30) }\end{array}$ & $\begin{array}{l}1,005 \\
\text { (bus 30) }\end{array}$ & $\begin{array}{l}1,005 \\
\text { (bus 30) }\end{array}$ \\
\hline $\operatorname{Vmin}_{1}(\mathrm{pu})$ & $\begin{array}{c}1,002 \\
\text { (bus 30) }\end{array}$ & $\begin{array}{c}0,976 \\
\text { (bus 15) }\end{array}$ & $\begin{array}{c}0,811 \\
\text { (bus 30) }\end{array}$ & $\begin{array}{c}0,999 \\
\text { (bus 30) }\end{array}$ & $\begin{array}{c}0,930 \\
\text { (bus 14) }\end{array}$ & $\begin{array}{c}0,857 \\
\text { (bus 23) }\end{array}$ \\
\hline $\operatorname{Vmax}_{1}(\mathrm{pu})$ & $\begin{array}{c}1,091 \\
\text { (Bus 11) }\end{array}$ & $\begin{array}{c}1,091 \\
\text { (Bus 11) }\end{array}$ & $\begin{array}{c}1,091 \\
\text { (Bus 11) }\end{array}$ & $\begin{array}{c}1,091 \\
\text { (Bus 11) }\end{array}$ & $\begin{array}{c}1,091 \\
\text { (Bus 11) }\end{array}$ & $\begin{array}{c}1,091 \\
\text { (Bus 11) }\end{array}$ \\
\hline Total Loss。 & $\begin{array}{c}7,110 \mathrm{MW} \\
2,081 \\
\text { MVAR }\end{array}$ & $\begin{array}{c}7,110 \mathrm{MW} \\
2,081 \\
\text { MVAR }\end{array}$ & $\begin{array}{c}7,110 \mathrm{MW} \\
2,081 \\
\text { MVAR }\end{array}$ & $\begin{array}{c}7,110 \mathrm{MW} \\
2,081 \\
\text { MVAR }\end{array}$ & $\begin{array}{c}\text { 7,110 MW } \\
2,081 \\
\text { MVAR }\end{array}$ & $\begin{array}{c}\text { 7,110 MW } \\
2,081 \\
\text { MVAR }\end{array}$ \\
\hline Total Loss 1 & $\begin{array}{c}6,855 \mathrm{MW} \\
1,664 \\
\text { MVAR }\end{array}$ & $\begin{array}{c}9,844 \mathrm{MW} \\
15,202 \\
\text { MVAR }\end{array}$ & $\begin{array}{c}13,693 \\
\text { MW } \\
21,129 \\
\text { MVAR }\end{array}$ & $\begin{array}{c}6,748 \mathrm{MW} \\
9,359 \\
\text { MVAR }\end{array}$ & $\begin{array}{c}12,363 \mathrm{MW} \\
26,120 \\
\text { MVAR }\end{array}$ & $\begin{array}{c}15,937 \mathrm{MW} \\
40,381 \\
\text { MVAR }\end{array}$ \\
\hline Saluran Pembatas & $6-8$ & $6-8$ & $6-8$ & $11-9$ & $14-15$ & $11-9$ \\
\hline
\end{tabular}

Tabel 3. Nilai ATC, dan Indeks $L$ pada bus penerima (q) sebelum dan setelah transfer daya dengan bus 13 sebagai bus pengirim (bus $p$ )

\begin{tabular}{|c|c|c|c|}
\hline & \multicolumn{3}{|c|}{ Transfer $(p \rightarrow q)$} \\
\hline & $13 \rightarrow 10$ & $13 \rightarrow 19$ & $13 \rightarrow 23$ \\
\hline ATC (pu) & 1,0706 & 1,0706 & 0,8727 \\
\hline Indeks $L_{o}$ Bus q & 0,0038 & 0,0048 & 0,0044 \\
\hline Indeks $L_{1}$ Bus q & 0,0286 & 0,1731 & 0,2383 \\
\hline Vbus $_{0}-q(p u)$ & 1,042 & 1,020 & 1,022 \\
\hline Vbus $_{1}-q(p u)$ & 0,958 & 0,597 & 0,739 \\
\hline $\operatorname{Vmin}_{\mathrm{o}}(\mathrm{pu})$ & $\begin{array}{c}1,005 \\
\text { (Bus 30) }\end{array}$ & $\begin{array}{c}1,005 \\
\text { (Bus 30) }\end{array}$ & $\begin{array}{c}1,005 \\
\text { (Bus 30) }\end{array}$ \\
\hline $\operatorname{Vmin}_{1}(p u)$ & $\begin{array}{c}0,949 \\
\text { (Bus 21) }\end{array}$ & $\begin{array}{c}0,597 \\
\text { (Bus 19) }\end{array}$ & $\begin{array}{c}0,739 \\
\text { (Bus 23) }\end{array}$ \\
\hline $\operatorname{Vmax}_{1}(\mathrm{pu})$ & $\begin{array}{c}1,091 \\
\text { (Bus 11) }\end{array}$ & $\begin{array}{c}1,091 \\
\text { (Bus 11) }\end{array}$ & $\begin{array}{c}1,091 \\
\text { (Bus 11) }\end{array}$ \\
\hline Total Loss。 & $\begin{array}{l}\text { 7,110 MW } \\
\text { 2,081 MVAR }\end{array}$ & $\begin{array}{l}\text { 7,110 MW } \\
\text { 2,081 MVAR }\end{array}$ & $\begin{array}{l}\text { 7,110 MW } \\
\text { 2,081 MVAR }\end{array}$ \\
\hline Total Loss & $\begin{array}{l}\text { 15,103 MW } \\
48,221 \text { MVAR }\end{array}$ & $\begin{array}{l}\text { 54.028 MW } \\
\text { 151.691 MVAR }\end{array}$ & $\begin{array}{l}\text { 30,161 MW } \\
72.503 \text { MVAR }\end{array}$ \\
\hline Saluran Pembatas & $13-12$ & $13-12$ & $23-15$ \\
\hline
\end{tabular}


Keterangan:

Daya dasar $=100 \mathrm{MVA}$

Indeks $L_{o}$ Bus q : Indeks $L$ bus penerima pada kondisi pembebanan awal

Indeks $L_{1}$ Bus q : Indeks $L$ bus penerima setelah transfer daya

Vbus $_{0}-\mathrm{q}(\mathrm{pu}) \quad$ : Tegangan bus penerima pada kondisi pembebanan awal

$\mathrm{Vbus}_{1}-\mathrm{q}(\mathrm{pu}) \quad$ : Tegangan bus penerima setelah transfer daya

$V_{m i n}(\mathrm{pu}) \quad$ : Tegangan minimum sistem tenaga pada kondisi pembebanan awal

$\mathrm{Vmin}_{1}(\mathrm{pu}) \quad$ : Tegangan minimum sistem tenaga setelah transfer daya

Kapabiltas transfer daya listrik berupa nilai ATC untuk ke-15 arah transfer diperlihatkan pada tabel 1, tabel 2 dan tabel 3. Nilai-nilai ATC tersebut diperoleh dari perhitungan ATC berdasarkan batasan termal, yaitu batasan kemampuan daya aktif saluran yang telah diperkurangkan dengan alokasi daya reaktif, seperti yang telah dilakukan oleh Santiago Grijalva, et al. (2003). Seperti ditunjukkan pada gambar 2, nilai ATC terendah sebesar 0,3008 pu (30,08 MW) diperoleh untuk transfer daya dari bus 8 ke bus $30(8 \rightarrow 30)$, sedangkan tertinggi untuk transfer daya $2 \rightarrow 7$, $13 \rightarrow 10$, dan $13 \rightarrow 19$, yaitu sebesar 1,0706 pu (107, $06 \mathrm{MW})$. Untuk transfer daya dari bus 1 dan bus 2 sebagai bus pengirim, saluran yang menjadi pembatas dan terbebani paling besar adalah saluran $4-12$, karena saluran ini merupakan saluran sentral untuk arah transfer tersebut dan mempunyai kemampuan daya semu maksimum $\left(S_{j k}^{\max }\right.$ ) cukup kecil, yaitu hanya 0,55 pu (55 MVA).

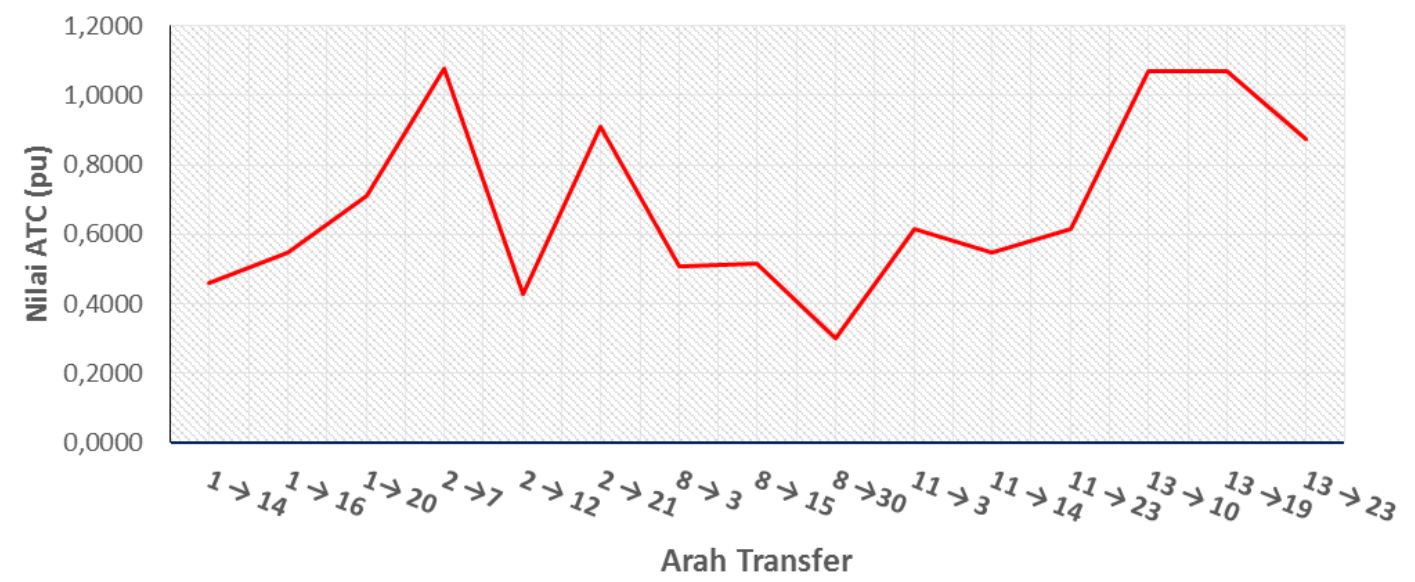

Gambar 2

Nilai ATC dari 15 arah transfer pada IEEE 30 bus test system

Simulasi transfer daya dilakukan dari suatu bus ke bus lain sebesar nilai-nilai ATC ini, untuk mengecek apakah batasan magnitude tegangan bus $\left(0,90 \mathrm{pu} \leq \mathrm{V}_{\text {Bus }}\right.$ $\leq 1,05 \mathrm{pu}$ ) dan batasan kestabilan tegangan statis bus, $(0 \leq L$ Index $\leq 1,0)$ terlampaui atau tidak. Semua bus-bus penerima atau bus tujuan transfer mengalami penurunan tegangan setelah transfer daya dilakukan, yaitu rata-rata 12\%. Ada 6 arah transfer yang menunjukkan penurunan tegangan pada bus penerima yang melampaui batas minimum atau dibawah 0,9 pu, yaitu transfer daya $1 \rightarrow 20,2 \rightarrow 21$, 
$8 \rightarrow 30,11 \rightarrow 23,13 \rightarrow 19$, dan $13 \rightarrow 23$. Penurunan drastis untuk transfer daya $13 \rightarrow 19$, dimana tegangan bus 19 menjadi 0,597 pu atau turun $41 \%$. Hal dapat dilihat pada gambar 3. Untuk ke-6 arah transfer ini jika diterapkan pada sistem tenaga listrik yang riil, transfer daya dilakukan dengan nilai daya yang lebih kecil dari nilai ATCnya sampai batasan tegangan minimum tidak terlampaui.

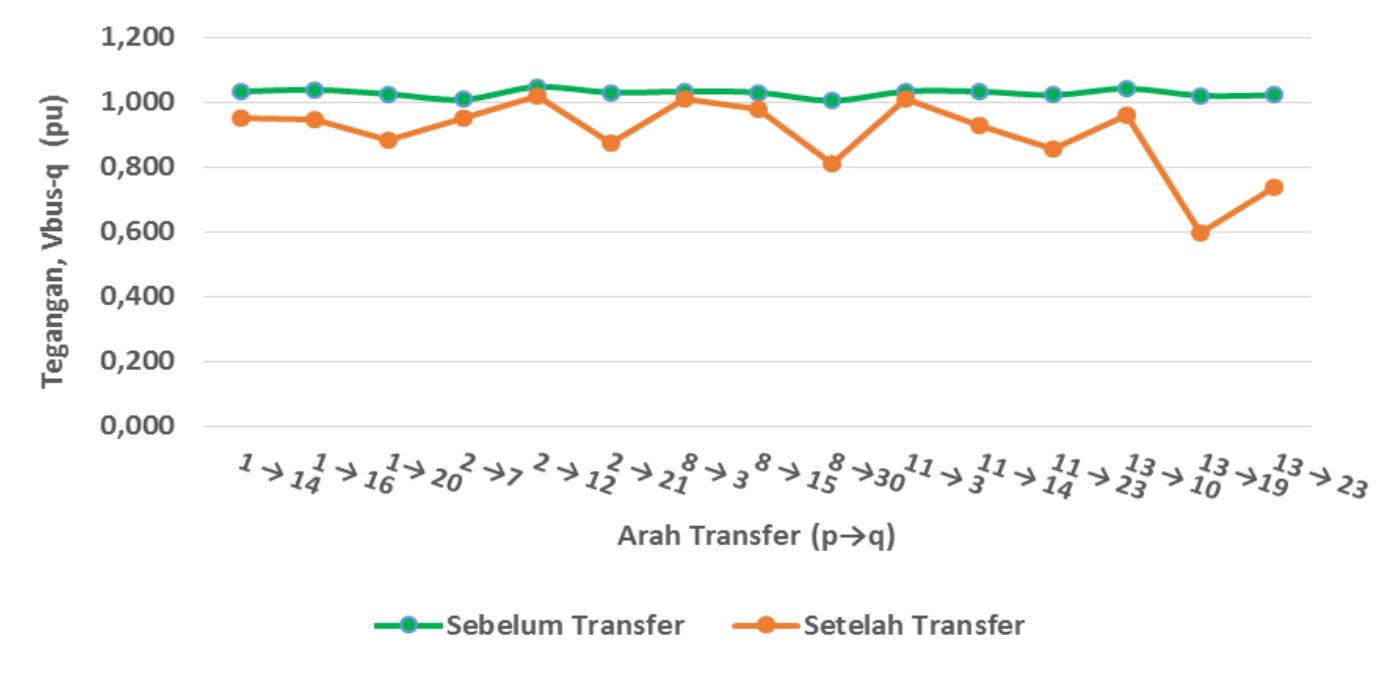

Gambar 3.

Profil tegangan pada bus penerima $\left(V_{\text {bus }}-q\right)$ sebelum dan sesudah transfer daya dari bus $p$ ke bus $q$ dari 15 arah transfer pada IEEE 30 bus test system

Dari 15 arah transfer yang berbeda, batasan kestabilan tegangan di tiap-tiap bus penerima tidak ada yang terlampaui jika dilakukan transfer daya sebesar nilai ATC-nya, artinya masih dalam level stabil atau masih jauh dari titik runtuhnya stabilitas tegangan sistem (jika $L$ Index $=1$ ). Hal ini dapat ditunjukkan pada kuva PV dan $L$ Index pada gambar 4 untuk transfer daya dari bus 13 ke bus $10(13 \rightarrow 10)$. Begitupun untuk arah transfer yang lain. Meskipun sistem masih jauh dari titik tidak stabilnya, tetapi $L$ index naik secara signifikan dengan rata-rata kenaikan 19 kali. Penurunan stabilitas tegangan terbesar atau kenaikan $L$ Index terbesar terjadi pada transfer daya daya dari bus 13 ke bus 23 ( $13 \rightarrow 23$ ), sebesar 53 kali lipat, atau menjadi 0,2383 . Hal ini dapat dilihat seperti yang ditunjukkan pada gambar 5 . 


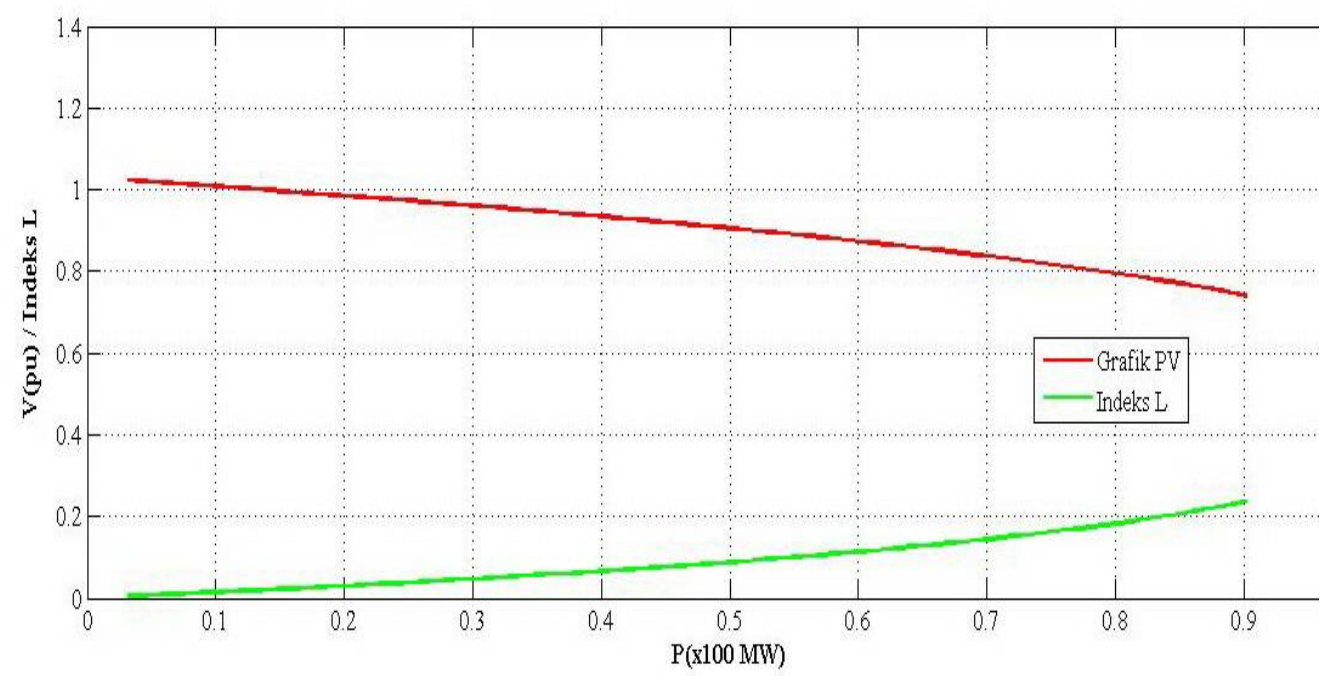

Gambar 4

Kurva PV dan L Index pada transfer daya dari bus 13 ke bus 10 pada IEEE 30 bus test system

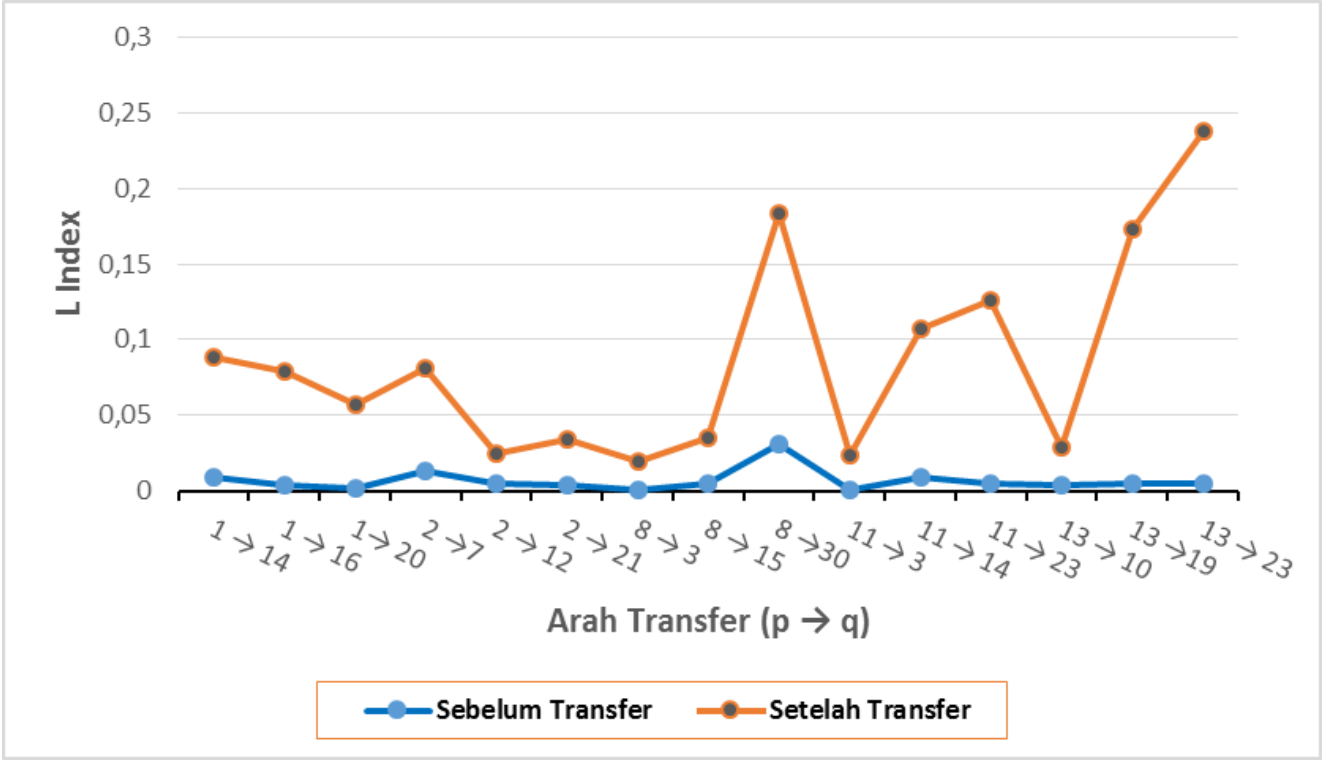

Gambar 5

Grafik $L$ Index sebelum dan sesudah transfer daya dari 15 arah transfer pada IEEE 30 bus test system

\section{KESIMPULAN}

Berdasarkan hasil analisis dari penelitian ini menunjukkan bahwa penentuan kapabilitas transfer daya listrik yang diperoleh berdasarkan batasan termal saja tidaklah cukup, tatapi harus juga mempertimbangkan batasan magnitude tegangan dan batasan stabilitas tegangan statis sistem tenaga. Pengecekan magnitude tegangan dan nilai kestabilan tegangan statis bus-bus setelah simulasi transfer daya dilakukan untuk memastikan bahwa perubahan 
tegangan bus pada sistem tenaga masih dalam batas-batas yang aman dan stabilitas tegangan sistem tenaga masil dalam level stabil atau masih jauh dari titik runtuhnya, apabila transfer daya pada setiap arah transfer sebesar nilai ATC-nya benar-benar dilakukan pada sistem tenaga yang riil.

\section{DAFTAR PUSTAKA}

Al Imran. (2006). Penggunaan Faktor Distribusi Perpindahan daya Nonlinear dan Pertimbangan Aliran Daya Reaktif dalam Perhitungan ATC. Jurnal ITENAS Bandung, No. 4, Vol. 10, Des. 2006 - Peb. 2007.

A. J. Wood and B. F. Wollenberg. (1996). Power Generation, Operation, and Control. John Wiley \& Sons, Inc., New York.

B. Stott and J.L. Marinho. (1979). "Linear Programming for power system network security applications", IEEE Transactions on Power Apparatus and Systems, Vol.PAS-98, No.3, pp. 837-848

G.C. Ejebe, J. Tong, J.G. Waight, J.G. Frame, X. Wang, and W.F. Tinney. (1998). "Available Transfer Capability Calculations", IEEE Transactions on Power System, vol. 13, no. 4, pp 1521-1527

Hadi Saadat. (2002), Power System Analysis, 2nd edition, McGraw-Hill, Inc., Singapore.

Huang, Garng M., and Ali Abur. (2002), Voltage Security Margin Assessment, PSERC Publication 02-49

K. Bavithra, S. C. Raja, and P. Venkatesh, 2016. "Optimal Setting of FACTS Devices using Particle Swarm Optimization for ATC Enhancement in Deregulated Power System," IFAC-PapersOnLine, vol. 49, no. 1, pp. 450-455.

M.A. Pai (1984), Computer Techniques In Power System Analysis, Tata McGraw-Hill Publishing Co. Ltd, New Delhi.

M. H. Gravener and C. Nwankpa. (1999). Available transfer capability and first order sensitivity, IEEE Transactions on Power System, vol. 14, no. 2, pp 512-518.

NERC Transmission Transfer Capability Task Force. (1995). Transmission Transfer Capability, North American Electric Realibility Council.

NERC Transmission Transfer Capability Task Force. (1996). Available Transfer Capability, Definition and Determination, North American Electric Realibility Council.

P. W. Sauer. (1997). "Technical challenges of computing Available Transfer Capability in electric power systems", Proceedings of the $30^{\text {th }}$ Annual Hawaii International Conference On System Sciences, Vol. V, Hawaii, pp. 589-593.

PowerWorld Corporation. (2004), PowerWorld Simulator User's Guide. http://www.powerworld.com

Santiago Grijalva, et al. (2003). "Enhancement of linear ATC calculations by the incorporation of reactive power flows", IEEE Transactions on Power System, vol. 18, no. 2, pp 619-624.

Santiago Grijalva and Peter W. Sauer. (1999), "Reactive power considerations in linear ATC computation", Proceedings of the $32^{\text {nd }}$ Hawaii International Conference On System Sciences. 
T. Nireekshana, G. K. Rao, and S. S. Raju. (2016). "Available transfer capability enhancement with FACTS using Cat Swarm Optimization," Ain Shams Engineering Journal, vol. 7, no. 1, pp. 159-167.

Y. R. H. Esmaili, A. M. A. Hemmatyar. (2012). "ATC Enhancement Using SSSC, a Case Study of Harmony Search Vs PSO," Journal of Basic and Applied Scientific Research, vol. 2, no. 4, p. 10, TextRoad Publication 